\title{
SITUATION OF REGULATIONS FOR HOLDING COMPANIES IN ROMANIA
}

\author{
Viorica Filofteia BRAGA ${ }^{1}$, Cristina Alina NĂFTĂNĂILA $\breve{A}^{1}$, Laurenția \\ AVRAM ${ }^{1}$ \\ 1 "Spiru Haret" University, Ion Ghica Street, no. 13, Bucharest, 030045, \\ Romania, Tel.: +40214551000, Fax: +40213143900, \\ Email:viobraga@yahoo.com,laura.avram@yahoo.com, \\ naftanailacristina@yahoo.com
}

\begin{abstract}
In this article I present the tax facilities applicable to Romania on holding companies, ranking of the first 20 countries that are investing in our country, their activity fields and the necessity to approve the law holding company.

Key words: holding companies; dividend tax; capital gains tax; law holding company.

JEL Classification: K22, M14, M41

\section{Introduction}

The concept of holding company is characterized by the following aspects:

- company whose objective is to acquire other companies in order to have a portfolio of shareholding titles to ensure its controlling position;

- holding company receives dividends from the controlled companies (subsidiaries) and participates in the financing of the award and/or guaranteeing of some loans made by subsidiaries and participation in the capital increase;

- objective of the holding companies can be:
\end{abstract}




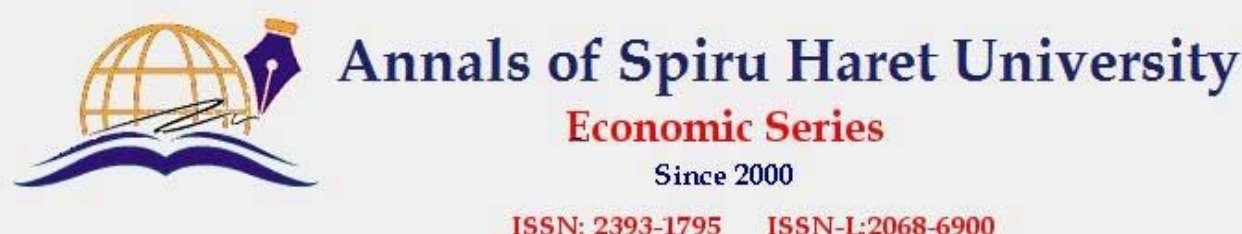

ISSN: 2393-1795 ISSN-L:2068-6900

Issue 2/2016

- pure (management of the held shareholdings titles);

- mixt (exercises and the commercial activities).

- object of activity falls within 6420 NACE code (activities of the holding companies)

Essentially, an ideal holding system allows intra-group transfer of resources without operational or legal barriers and without additional costs, such as those concerning the taxation. In this respect, the basic condition to be satisfied is not taxed or modest tax of 1-2\% of the capital gains and the dividend income derived from the sale, respectively owning the shareholdings in subsidiaries. To avoid encouraging the speculative investments, application of such provisions is often conditioned by a quota or a minimum owning period for shareholdings in subsidiaries.

The holding structure should serve the needs of the global management and, at the same time, to ensure the financing needs or to centralize the management of the intellectual property rights used at the group level. Just such requirements have led to a specialization of holding companies: financing in Luxembourg and the Netherlands, or intellectual property in Ireland. In addition, the holding specialization imposed them as separate entities from those established for the shareholdings management.

The tax and legal regulation of these entities differs from country to country. In Romania, until now there are only tax regulations.

\section{Provisions for Tax Holding Companies in Romania}

From 2014, the system of holding tax is regulated by the Tax Code. Thus, in Romania, there are, for the first time, the holding tax provisions. It is about a simple system that meets the minimum two conditions for the holding operation: tax exemptions on the capital gains and dividends.

Meanwhile, from the beginning of that year, there are not taxed any liquidation proceeds obtained by the holding company from the sale of the shareholding titles in subsidiaries that are owned. At the same time, in our country there was established as well a minimum holding period of one year. These provisions were taken over in the new law on the Tax Code, Law no. 227/2015 applicable from 01.01.2016. 

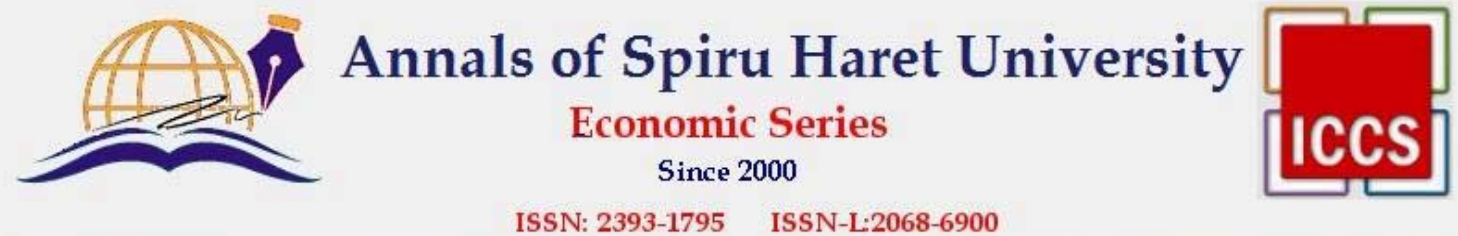

Issue 2/2016

The articles of the Tax Code which make reference to what I have mentioned above are:

- Article 23, mentioning that in calculating the taxable profit, the following incomes are non-taxable:

a) dividends received from a Romanian legal entity or from a foreign entity paying income tax or a similar tax to the profit tax, located in a third country with which Romania has concluded an agreement for avoidance of double taxation, if the Romanian legal entity that receiving dividends holds on the foreign legal entity in the third, on the date of their registration according to the applicable accounting regulations, for a continuous period of one year, minimum of $10 \%$ of the share capital of the legal entity that is distributing the dividends;

b) income from the evaluation / revaluation / sale / transfer of shareholding titles held by a Romanian legal entity or a foreign entity located in a state with which Romania has concluded an agreement for avoidance of double taxation, if on the date of the evaluation / revaluation / sales / transfers, the taxpayer holds, for an uninterrupted period of one year, at least $10 \%$ of the share capital of the legal entity, where he has shareholding titles. Not covered by these provisions are the incomes from the sale / transfer of shareholdings titles held on a Romanian legal entity by the resident legal entity in a state with which Romania has not concluded an agreement for avoidance of double taxation;

c) incomes from the liquidation of another Romanian legal entity or a foreign legal entity located in a state with which Romania has concluded an agreement for the avoidance of double taxation, if on the date of commencement of operation of liquidation, according to the law, the taxpayer holds, for an uninterrupted period of one year, at least $10 \%$ of the share capital of the legal entity subjected to liquidation;

- Article 24. The fiscal regime of the dividends received from Member States of the European Union. After Romania's accession to the European Union, there are also non-taxable:

a) dividends distributed to a Romanian legal entity, the parent company, by its subsidiary located in a Member State, including those distributed to its permanent establishment situated in another Member State than that of the subsidiary, if the Romanian legal entity meets the following conditions: 


\section{Annals of Spiru Haret University \\ Economic Series \\ Since 2000}

ISSN: 2393-1795 ISSN-L:2068-6900

\section{Issue 2/2016}

1) has one of the following forms of organization: general partnership, limited partnership, limited company, limited partnership by shares, limited liability company;

2) pay income tax under the provisions of Title II, without possibility of an option or exception;

3) holds a minimum $10 \%$ of the share capital of the subsidiary situated in another Member State, which distributes dividends;

4) on the date of income dividends registration, it holds the minimum participation from section 3 , for an uninterrupted period of at least one year;

b) dividends distributed to the foreign legal entities of Member States, parent companies, by their subsidiaries situated in other Member States through permanent establishments in Romania, if the foreign legal entity meets all the following conditions:

1) has one of the forms provided in Annex no. 1, Title II; Income tax of the Tax Code;

2) in accordance with the tax legislation of the Member State it is considered to be resident in that Member State and, under an agreement concluded with a third country to avoid the double taxation, it is not considered to have the fiscal headquarters outside the European Union;

3) paid, in accordance with tax legislation of a Member State, without the possibility of an option or exception, one of the taxes provided in Annex no. 2, Title II; Income tax of the Tax Code;

4) holds a minimum $10 \%$ of the share capital of the subsidiary situated in another Member State, which distributes dividends;

5) on the date of income dividends registration by permanent headquarters in Romania, the foreign legal entity holds the minimum participation provided in section 4 , for an uninterrupted period of at least one year.

In case that on the date of income dividends registration, the condition relating to the period to the minimum holding period of one year is not met, the income is subject to taxation. Subsequently, in the tax year in which the condition is satisfied, the income is considered non-taxable with the tax recalculation of the tax year in which it was imposed. 

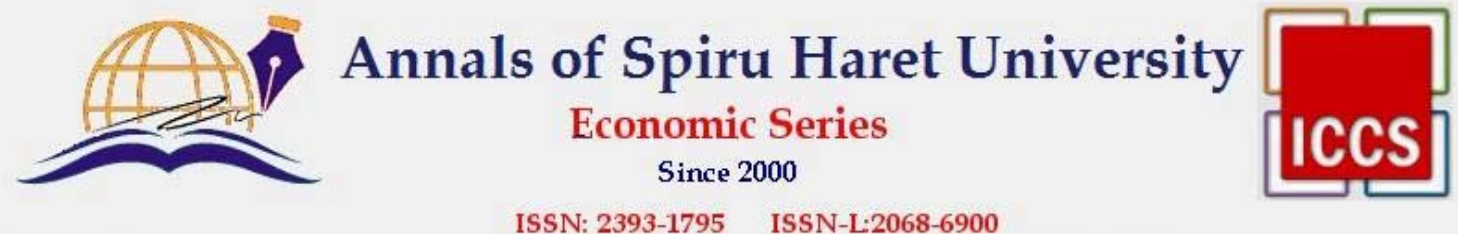

ISSN: 2393-1795 ISSN-L:2068-6900

Issue 2/2016

In this respect, the taxpayer must submit an amendment declaration of the profit tax, as provided by the Fiscal Procedure Code.

Of course, the fiscal novelties are targeting the strategic investments that aim to the development, rather than the speculative.

For this reason, the most countries with holding regime require minimum thresholds to hold shares to grant tax exemption on dividends.

For example, Netherlands has a share of 5\% and Cyprus, $1 \%$.

Romania has chosen to impose ownership of at least $10 \%$ of shares in a subsidiary from which they receive dividends.

\section{Comparison between Romania and Cyprus on the Business Environment of the Holding Companies}

Next, we made a comparison between the business community of Cyprus and Romania, given that in 2014, by regulating the holding fiscal regime, Romania became as friendly to investors as countries such as Cyprus or Netherlands.

In Romanian legislation could be found the following:

$>$ Pluses

- tax exemption for capital gains (sale of shareholders titles, dividend income and income from liquidation);

- $16 \%$ tax on profits and income, VAT $24 \%$;

- extensive system of treaties to avoid the double taxation;

- modern law of the commercial companies.

$>$ Minuses

- missing the fiscal consolidation in group;

- the anticipated tax solutions and advance pricing agreements are obtained very hard;

- unstable and unpredictable legislation.

Also, it is required to the beneficiary (Romanian legal entity) holding a minimum of $10 \%$ of the share capital of that company for a continuous period of one year.

In addition, Romania is currently very close to the regulations of the traditional jurisdictions in Europe. 


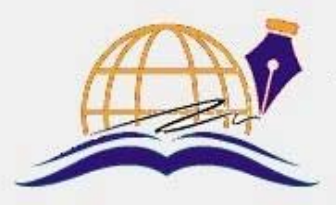

Annals of Spiru Haret University

Economic Series

Since 2000

ISSN: 2393-1795 ISSN-L:2068-6900

\section{Issue 2/2016}

Cypriot legislation on the taxation of holding companies is characterized by the following:

$-10 \%$ profit tax, $15 \%$ VAT;

- dividends are not taxed;

- there is the fiscal consolidation (cumulating the profits and losses in the group);

- there is no tax on the social capital contribution or increase it;

- there is no tax for social shares;

- there is no tax on the sale of shares;

- developed system of treaties to avoid the double taxation.

\section{Statistical Situation of the Companies with Foreign Participation} in Romania on 31 December 2015

Statistics of the Trade Register indicate the Netherlands as the largest foreign investor in the national economy.

Over 4,700 companies have shareholders residing in the Land of Tulips.

In addition, among the first ten countries, both in number of companies and the value of the subscribed capital, there are: Austria, Germany and Cyprus

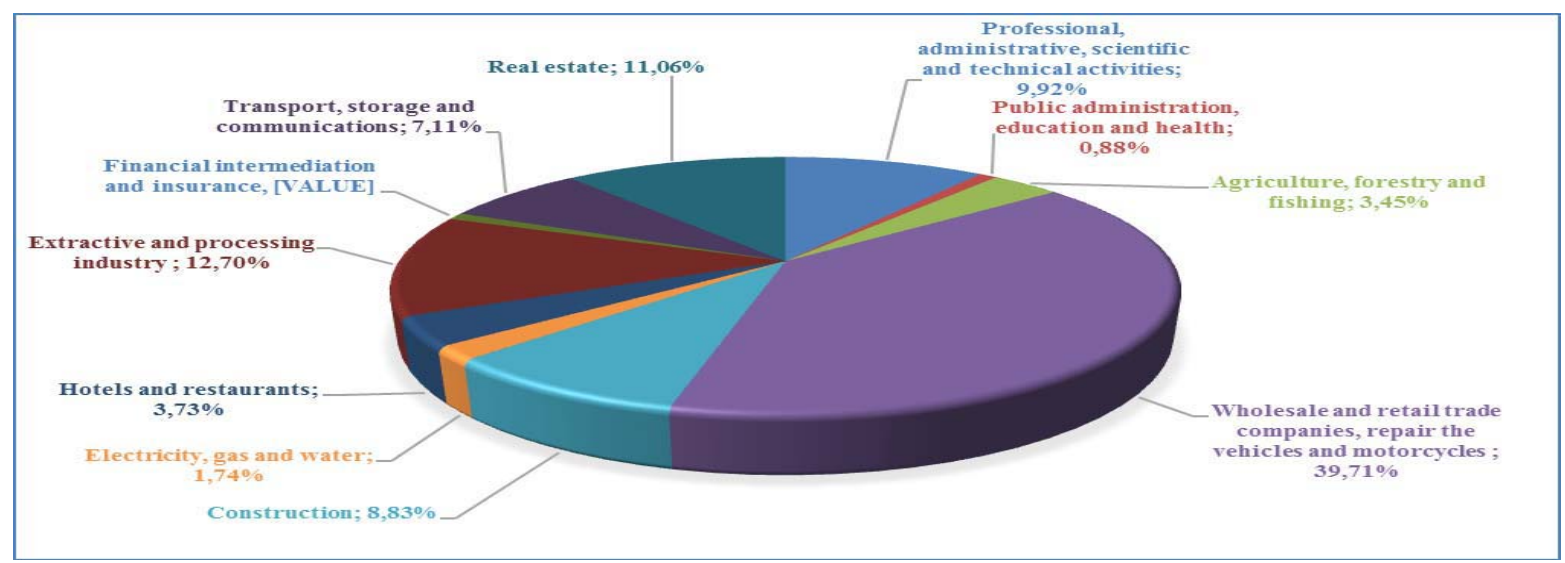

Chart no. 1. Structure by domains of activity of the number of companies with foreign participation

Source: own chart 


\section{Annals of Spiru Haret University \\ Economic Series \\ Since 2000 \\ ISSN: 2393-1795 ISSN-L:2068-6900}

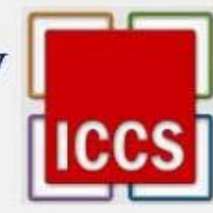

Issue 2/2016

Analysing the Chart no. 1 Structure by domains of activity of the number of companies with foreign participation, one can notice that the biggest share is hold by a number of wholesale and retail trade companies, repair the vehicles and motorcycles $(39.71 \%)$, and followed by extractive and processing industry $(12.70 \%)$ and real estate transactions $(11.06 \%)$.

Table no. 1. Ranking of the first 20 countries of residence, of the investors in the companies with foreign participation in the share capital on 31 December 2015

\begin{tabular}{|c|c|c|c|c|c|c|c|c|c|}
\hline \multirow{3}{*}{ No. } & \multirow{3}{*}{ Country } & \multirow{2}{*}{\multicolumn{2}{|c|}{$\begin{array}{c}\text { Companies } \\
\text { with } \\
\text { foreign } \\
\text { participatio } \\
n \\
\end{array}$}} & \multicolumn{6}{|c|}{ Amount of subscribed social capital } \\
\hline & & & & \multicolumn{2}{|c|}{$\begin{array}{l}\text { Total in local } \\
\text { currency }\end{array}$} & \multicolumn{2}{|c|}{$\begin{array}{c}\text { Total in } \\
\text { equivalent of } \\
\text { currency }\end{array}$} & \multicolumn{2}{|c|}{$\begin{array}{c}\text { Total in } \\
\text { equivalent of } \\
\text { currency }\end{array}$} \\
\hline & & No. & $\%$ & $\begin{array}{c}\text { thousands } \\
\text { Lei }\end{array}$ & $\%$ & $\begin{array}{c}\text { thousands } \\
\text { USD }\end{array}$ & $\%$ & $\begin{array}{c}\text { thousands } \\
\text { EUR }\end{array}$ & $\%$ \\
\hline 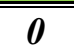 & 1 & \multicolumn{2}{|l|}{2} & \multicolumn{2}{|l|}{3} & \multicolumn{2}{|l|}{ 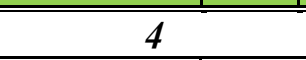 } & \multicolumn{2}{|l|}{5} \\
\hline & Total ROMANIA & \multicolumn{2}{|l|}{204,4661} & \multicolumn{6}{|c|}{\begin{tabular}{|l|l|l|}
$56,989,118.9$ & $100.00|42,808,890.3| 100.00$
\end{tabular}} \\
\hline 1 & NETHERLANDS & 4,761 & 2.36 & $32,603,116.5$ & 21.57 & $11,716,524.5$ & 21.17 & $8,414,982.9$ & 21.25 \\
\hline 2 & AUSTRIA & 7,041 & 3.49 & $16,495,295.4$ & 10.92 & $7,045,585.2$ & 12.73 & $4,872,386.8$ & 12.30 \\
\hline 3 & GERMANY & 21,106 & 10.46 & $14,636,078.2$ & 9.69 & $6,474,698.5$ & 11.70 & $4,557,799.9$ & 11.51 \\
\hline 4 & CYPRUS & 5,721 & 2.84 & $15,478,668.5$ & 10.24 & $5,074,133.8$ & 9.17 & $3,793,820.9$ & 9.58 \\
\hline 5 & $F R A N C E$ & 8,322 & 4.12 & $9,628,732.1$ & 6.37 & $3,425,880.2$ & 6.19 & $2,434,275.2$ & 6.15 \\
\hline 6 & GREECE & 6,278 & 3.11 & $6,485,425.4$ & 4.29 & $2,535,291.6$ & 4.58 & $1,779,601.2$ & 4.49 \\
\hline 7 & ITALY & 41,759 & 20.70 & $5,940,696.1$ & 3.93 & $2,263,189.5$ & 4.09 & $1,579,892.1$ & 3.99 \\
\hline 8 & SPAIN & 5,534 & 2.74 & $6,636,686.2$ & 4.39 & $2,215,877.9$ & 4.00 & $1,655,577.6$ & 4.18 \\
\hline 9 & LUXEMBOURG & 847 & 0.42 & $5,542,787.7$ & 3.67 & $1,868,213.6$ & 3.38 & $1,367,782.5$ & 3.45 \\
\hline 10 & \begin{tabular}{|l|} 
UNITED \\
KINGDOM \\
\end{tabular} & 5,205 & 2.58 & $3,859,019.8$ & 2.55 & $1,425,605.0$ & 2.58 & $1,010,315.8$ & 2.55 \\
\hline 11 & SWITZERL & 2,669 & 1.32 & $3,076,032.6$ & 2.04 & $4,147.6$ & 2.41 & 31,384. & 2.35 \\
\hline 12 & $U S A$ & 7,076 & 3.51 & $3,445,700.3$ & 2.28 & $1,333,972.2$ & 2.41 & $950,061.2$ & 2.40 \\
\hline 13 & HUNGARY & 12,990 & 6.44 & $3,128,871.7$ & 2.07 & $1,187,429.1$ & 2.15 & $864,014.9$ & 2.18 \\
\hline 14 & TURKEY & 14,369 & 7.12 & $1,979,515.9$ & 1.31 & $761,492.3$ & 1.38 & $545,252.3$ & 1.38 \\
\hline 15 & $\begin{array}{l}\text { CZECH } \\
\text { REPUBLIC }\end{array}$ & 893 & 0.44 & $2,212,100.8$ & 1.46 & $748,710.6$ & 1.35 & $559,796.5$ & 1.41 \\
\hline 16 & $\begin{array}{l}\text { NETHERLANDS } \\
\text { ANTILLES }\end{array}$ & 15 & $* * *$ & $2,042,294.6$ & 1.35 & 50.5 & 1.31 & 7.0 & 1.27 \\
\hline 17 & BELGIUM & 3,442 & 1.71 & $1,402,134.6$ & 0.93 & $543,969.5$ & 0.98 & $396,414.9$ & 1.00 \\
\hline 18 & POLAND & 862 & 0.43 & $1,746,126.9$ & 1.16 & $496,027.3$ & 0.90 & $383,978.8$ & 0.97 \\
\hline 19 & CHINA & 11,834 & 5.86 & $1,177,923.8$ & 0.78 & $440,894.5$ & 0.80 & $314,583.2$ & 0.79 \\
\hline 20 & SWEDEN & 1,384 & 0.69 & $1,037,799.0$ & 0.69 & $379,437.9$ & 0.69 & $268,899.8$ & 0.68 \\
\hline
\end{tabular}




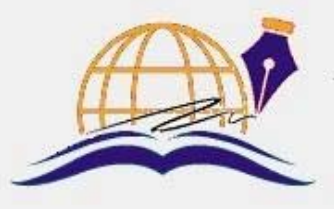

Annals of Spiru Haret University

Economic Series

Since 2000

ISSN: 2393-1795 ISSN-L:2068-6900

\section{Issue 2/2016}

Analysing the Chart no. 2 Structure on the domains of activity of the share capital value, subscribed by the companies with foreign participation at the share capital, one can notice that the most was invested in extractive and processing industry $(35.70 \%)$.

This area is followed by financial intermediation and insurance $(17.36 \%)$ and wholesale and retail trade companies, repair the vehicles and motorcycles $(12.45 \%)$. registration costs.

Developing the holding companies is also stimulated by the

For example, the companies that are running large businesses choose Netherlands, where the registration costs and the annual ones for the activity of the business are each around 25,000 Euros. Cyprus is cheaper, the costs are around 5,000 Euros.

The regime of holding companies from the traditional countries such as Cyprus, Netherlands, Switzerland and Luxembourg is complete, both in terms of tax and the legislation on companies.

\section{Necessity for approving the holdings law}

The holding draft law is in Parliament and has not been approved yet. If approved, the regime of holding company will have the following characteristics:

- sets out the legal and fiscal regime of the group of companies and holding companies, and the general framework of economic, financial and legal relationships between holding companies and subsidiaries;

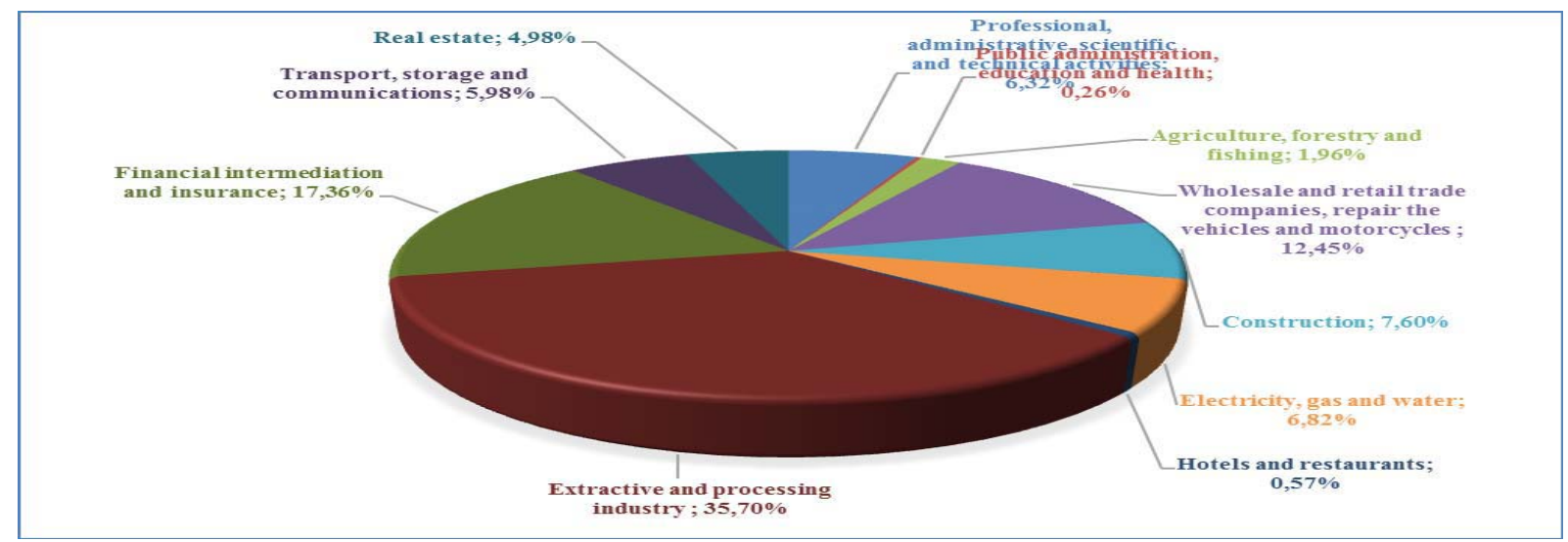

Chart no. 2. Structure on the domains of activity of the share capital value, subscribed by the companies with foreign participation at the share capital, registered in December 2015

Source: $\mathrm{http}: / /$ www.onrc.ro/index.php/ro/statistici?id=254

*) Calculated according to the main declared activity

**) Calculated according to the total share capital subscribed in currency (USD) 


\section{Annals of Spiru Haret University \\ Economic Series \\ Since 2000}

ISSN: 2393-1795 ISSN-L:2068-6900

Issue 2/2016

- a holding company can be associated with one or more subsidiaries;

- a subsidiary (SRL company), having the holding company a single associate, can be the single associate of another SRL on condition that each of these companies to conduct commercial activity in their own name;

- holding company may conduct administration, supervision and control activity of the subsidiaries activity;

- holding company may grant funding to the subsidiaries;

- it is established the obligation of drafting and filing of both the individual annual financial statements and the consolidated annual financial statements;

- group of companies will be treated fiscally as a single economic entity carrying on an integrated activity;

- intra-group transactions are fiscally neutral, being treated as transfers of goods and services produced within the same entity;

- income tax is applied to the consolidated financial result (will be due and pay by the group companies in proportionate quota established in the holding);

- tax losses of the companies are not reported if they are not consumed through consolidation;

- VAT is not applicable in intra-group transactions;

- recoverable VAT of a company can be compensated with VAT owed by another company in the group;

- a group company must be designated responsible for reporting and preparation of the consolidated statement of VAT, respectively of payment of VAT resulting from consolidation;

- tax on dividends made by the companies members of a group is due and is payable only once by the holding company.

This law will have an important macroeconomic and socio-economic impact to the business environment in Romania ${ }^{1}$.

The macroeconomic impact - adoption of the law would be a clear evidence of raising the quality of national legislation in the corporate law

\footnotetext{
${ }^{1}$ Explanatory memorandum on the law holding company
} 


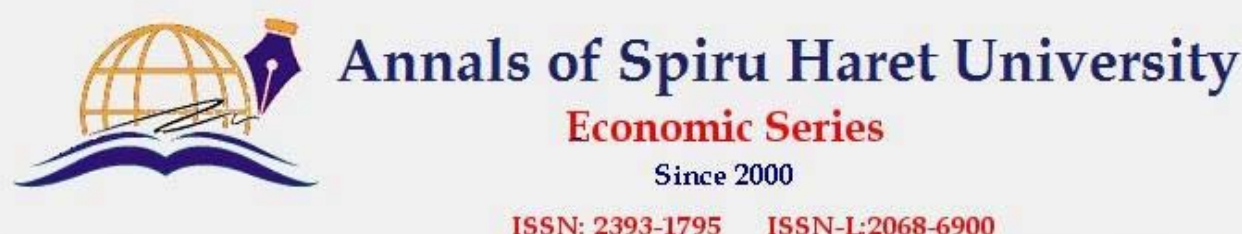

ISSN: 2393-1795 ISSN-L:2068-6900

\section{Issue 2/2016}

field to the advanced level of the member countries of the European Union and would be an important step forward toward the establishment of holding companies in the single market framework where can participate the countries with Romanian capital, which will enter Romania in a globalist context.

The impact on business environment - the establishment and enforcement of the holding companies law will lead to more efficiency and streamline the business conducted by economic operators in the country and will attract the formation of holding companies with Romanian or foreign capital, thereby helping to improve the local business environment and increasing the interest of foreign investors.

As a result of going through the processes of merger and / or acquisition, a number of SMEs with domestic capital might constitute in holding companies, benefiting from increased turnover, bargaining power to suppliers and creditors or training and promoting of their brands etc.

Encouraged by a favourable economic climate, the investors will be more careful in their opportunities of own local business development without putting the problem of capital transition from one jurisdiction to another. All these will have a beneficial effect on the financial system in Romania.

Although, on the short-term, implementing the holding legislation will not give rise to direct benefits for the authorities, the indirect positive impact will be found on medium and long term. So, if it develops, the holding legislation will boost further the establishment of new companies and help develop the related services, but the effect in the economy will be measured over time, as changes cannot be dramatic, from one day to another.

Specifically, the establishment of holding companies in Romania will encourage the development of collateral activities, the professions being targeted first (accounting, legal services, consulting). In addition, there would be the development of new jobs in the high qualification sectors.

However, a holding company regime will encourage domestic capital preservation in the country, increasing the chances of Romania to impose against the tax competition from outside. Also, the ideal scenario would turn Romania into a pole of reference between jurisdictions in the region. 

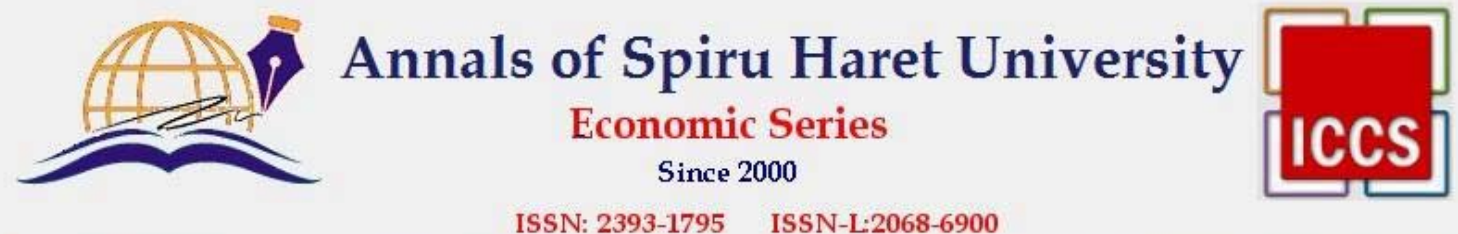

Issue 2/2016

However, it remains only to succeed to implement holding laws while still represents an innovation and not a necessity to counter the fiscal policy of the neighbouring countries.

In addition, the advantages offered by Romania and other European Union countries cannot be compared with tax havens: British Virgin Islands or the Cayman Islands, where there is no income tax. Thus, companies that pursue the speculative investment will be further attracted to such areas where the extracting money from business is not taxed.

\section{Conclusions}

Developing a national economy depends largely on the evolution of large and powerful companies, those with enough force to stimulate research and innovation, to employ others and conclude collaboration with many small and medium enterprises around them.

Analysing the statistics of the Trade Register indicates the Netherlands as the largest foreign investor in the national economy. Over 4,700 companies have shareholders residing in the Land of Tulips. In addition, among the first ten countries, both in number of companies and the value of the subscribed capital, there are: Austria, Germany and Cyprus.

A first step in this direction was made in Romania by the tax incentives approved in 2014, and republished in the new Fiscal Code which applies starting from $1^{\text {st }}$ of January 2016 and refers to non-taxation of dividends, income from the sale/transfer of shareholding titles and income from the liquidation of another Romanian legal entity or a foreign legal entity located in a state with which Romania has concluded a double taxation convention. Also, there are stimulated speculative transactions by requiring a minimum percentage holding $-10 \%$ of the share capital of that company for a continuous period of one year.

By analysing the advantages and disadvantages offered by the business environment in Romania it results the increasing of the attractive business environment through regulations approved since January 2014.

It is believed that the publication of the holding companies law would generate greater attractiveness for business environment in Romania because it allows intra-group transfer of resources without operational or 


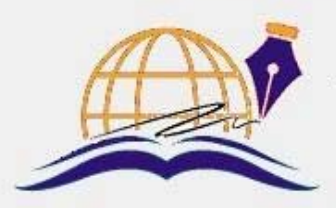

Annals of Spiru Haret University

Economic Series

Since 2000

ISSN: 2393-1795

ISSN-L:2068-6900

\section{Issue 2/2016}

legal barriers and also the reduction of the taxation rate. Moreover, the establishment of holding companies in Romania will encourage the development of collateral activities, the professions being targeted first (accounting, legal services, consulting).

\section{References}

1. Accounting Law no. 82/1991 (r4). Republished in the Official Gazette no. 454 of $18^{\text {th }}$ of June 2008.

2. Government Decision 1/2016 on rules for the application of Law no. 227/2015 regarding the Fiscal Code, Official Gazette no. 22 of January 13, 2016.

3. http://www.cameradeputatilor.ro/pls/proiecte/upl_pck.proiect?cam=2\&idp=106 41.

4. http://www.onrc.ro/index.php/ro/statistici?id=254.

5. Law no. 227/2015 on the Fiscal Code, published in the Official Gazette no. 688 of September 10, 2015.

6. Law no. 31/1990 on trading companies. Republished in the Official Gazette no. 1066 of $17^{\text {th }}$ of November 2004, with subsequent amendments.

7. Law no. 571/2003 regarding the Fiscal Code, published in the Official Gazette no. 927 of $23^{\text {rd }}$ of December 2003, with subsequent amendments. 